\title{
Geographic variation among Iberian communities of the exotic halophyte Cotula coronopifolia
}

\author{
José Carlos Costa $\cdot$ Carlos Neto $\cdot$ \\ Pedro Arsénio $\cdot$ Jorge Capelo
}

Received: 11 July 2008/Accepted: 18 June 2009/Published online: 24 July 2009

(c) Birkhäuser Verlag, Basel/Switzerland 2009

\begin{abstract}
The exotic annual forb Cotula coronopifolia has locally invaded salt marsh communities naturally dominated by Spergularia marina along large parts of the Iberian coastline. While the floristic composition of C. coronopifolia dominated communities on the Atlantic coast of northern Portugal has already been described, this information was missing for the southern part of the country. We carried out a phytosociological study at 21 sites along the south-western and southern coast of mainland Portugal to determine the ecology and syntaxonomical status of these communities, and to compare them to the Atlantic ones. Plant communities co-dominated by C. coronopifolia and S. marina were generally found in the
\end{abstract}

Responsible Editor: Sabine Güsewell.

\section{J. C. Costa ( $\square)$}

Departamento de Protecção de Plantas e de Fitoecologia,

Instituto Superior de Agronomia,

Technical University of Lisbon (TULisbon),

Tapada da Ajuda, 1349-017 Lisbon, Portugal

e-mail: jccosta@isa.utl.pt

\section{Neto}

Departamento de Geografia, Faculdade de Letras de Lisboa,

Alameda da Universidade, 1600-214 Lisbon, Portugal

e-mail: carlosneto@fl.ul.pt

\section{P. Arsénio}

Secção Autónoma de Arquitectura Paisagista, Instituto Superior de Agronomia,

Technical University of Lisbon (TULisbon),

Tapada da Ajuda, 1349-017 Lisbon, Portugal

e-mail: arseniop@isa.utl.pt

\section{J. Capelo}

Instituto Nacional de Recursos Biológicos, I. P., Quinta do Marquês, 2780-159 Oeiras, Portugal

e-mail: jorge.capelo@gmail.com sub-halophilous inner part of salt marshes. They occupied gaps within taller perennial vegetation (Juncus maritimus formations), such as small pools temporarily inundated with brackish waters. Southern communities differed from the northern ones by the high abundance of Triglochin barrelieri and the absence of salt-intolerant species that are present in the Atlantic communities. This difference may result from the drier summer climate in southern regions, leading to intense water evaporation and thus, more saline conditions. We propose to classify the Mediterranean communities in a new association, the Cotulo coronopifoliae-Triglochinetum barrelieri. High abundance of Limonium diffusum further allowed the distinction of a new subassociation limonietosum diffusi for the southernmost part of Portugal. Results show that invasive exotic plants can form new phytosociological associations with a characteristic species composition, but that these community types, despite being dominated by the same invader, still show ecological and geographical differentiation.

Keywords Iberian Peninsula · Phytosociology · Pioneer vegetation $\cdot$ Salt marshes $\cdot$ Syntaxonomy

\section{Introduction}

Cotula coronopifolia (Compositae) is a yellow-flowered forb with succulent leaves, occupying the edges of salt marshes on damp, muddy and salty soils. It is native to South Africa (Franco 1984) but has spread through the coasts of Europe, South and North America, New Zealand, Australia and Tasmania (Coutinho 1939; Hultén 1968; Ramírez et al. 1989; Bueno 1997). In temperate Europe, C. coronopifolia is an annual plant (Partridge and Wilson 1987; Bueno 1997), whereas in its original territory, South 
Africa, it is sometimes perennial, with longer stems trailing and rooting (Manning and Golblatt 1996). In Portugal, the species is predominantly annual north of Tagus River and perennial southwards, where the Mediterranean climate is more similar to that of South Africa.

The spread of $C$. coronopifolia is promoted by its ability to colonize a wide range of extreme habitats, including beaches, estuaries, intertidal flats, disturbed salt marshes and human-disturbed inland sites (Van der Toorn 1980). An effective aquatic dispersion of seeds (up to $450 \mathrm{~m} / \mathrm{year}$; van der Toorn 1980) enables the species to rapidly colonize disturbed places, where it can form almost pure stands thanks to its fast seed germination (Partridge and Wilson 1987; Van der Toorn 1980; Van der Toorn and ten Hove 1982). As a consequence, Campos et al. (2004) considered C. coronopifolia an accidentally introduced, invasive plant for Spain. In France, $C$. coronopifolia is regarded as a 'restricted' invasive species in aquatic plant communities of the Mediterranean region and as 'potentially invasive' in the Atlantic region, although it is not included in the group of the most dangerous invasive plants (Thiébaut 2007).

Plant invasions raise new questions for phytosociology. Traditionally, phytosociology assumes that plant communities consist of characteristic species assemblages reflecting abiotic conditions as well as biotic interactions. Invasive exotic plants can alter both abiotic conditions and biotic interactions in multiple ways. This may cause exotic plant invaders to assemble new types of plant communities around them. Alternatively, invaded plant communities may retain their characteristic native species composition despite the presence of a competitive invader. So far, it is not possible to predict for a particular exotic species what the effect of its invasion on native communities will be. It also appears that the species composition of invaded communities is sometimes determined by habitat conditions similarly to native communities, whereas in other cases the influence of the dominant exotic invader overrides habitat factors, leading to a homogenization of the vegetation.

Two phytosociological associations dominated by C. coronopifolia have been described from the north-western part of the Iberian Peninsula: the Spergulario marinaeCotuletum coronopifoliae on Asturian estuaries (Bueno 1997) and the Triglochino striatae-Cotuletum coronopifoliae on Galician-Portuguese estuaries (Alves 2004). Both communities occur in sub-halophilous openings within J. maritimus communities; these are small ponds with barely saline water due to the humid climate of north-western Iberia (Díaz González and Fernández Prieto 2005). Similar sites also occur along the Mediterranean coast in southern Iberia, and some of them are also colonized by $C$. coronopifolia. However, their syntaxonomy and ecology has not yet been studied in detail.

The aims of this study were (1) to describe the species composition and ecology of communities invaded by C. coronopifolia in southern Iberia, (2) to determine whether and how they differ from those in northern Iberia, and (3) to examine their relationship with uninvaded communities
Fig. 1 Geographic location of the analyzed salt marsh communities

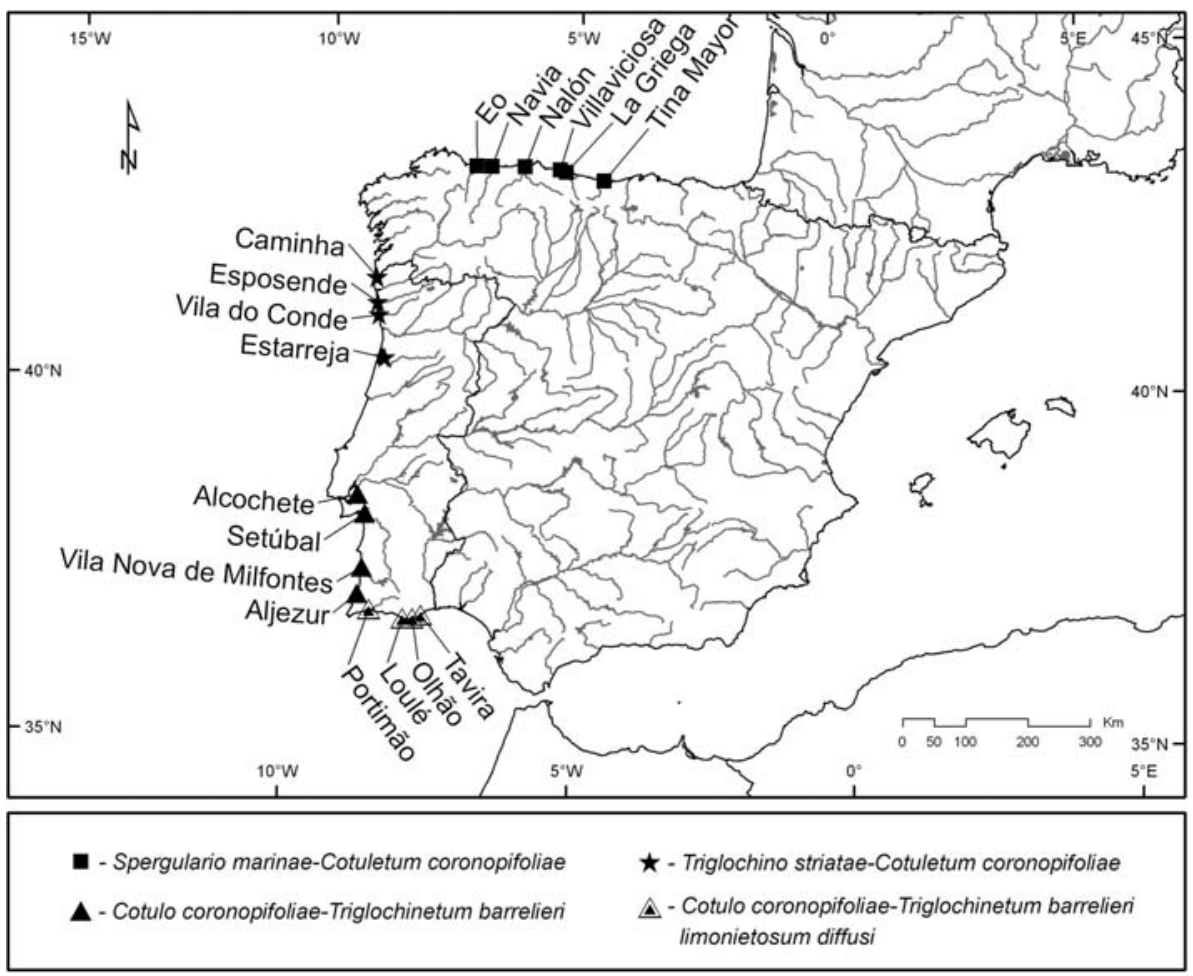


Table 1 Synthetic table of Cotula coronopifolia communities of the Iberian Peninsula

\begin{tabular}{llllll}
\hline Community type & 1 & 2 & 3 & 4 & 5 \\
Number of relevés & 58 & 10 & 8 & 7 & 10 \\
\hline
\end{tabular}

Characteristics and differentials of associations

\begin{tabular}{|c|c|c|c|c|}
\hline Cotula coronopifolia & $\mathrm{V}$ & V & $\mathrm{V}$ & $\mathrm{V}$ \\
\hline Spergularia marina & V & IV & $\mathrm{V}$ & $\mathrm{V}$ \\
\hline Triglochin maritima & III & . & . & . \\
\hline Puccinellia fasciculata & III & . & . & . \\
\hline Parapholis strigosa & II & . & . & . \\
\hline Puccinellia maritima & II & . & . & . \\
\hline Polypogon monspeliensis & II & . & . & . \\
\hline Juncus ambiguus & II & . & . & . \\
\hline Juncus gerardii & II & . & . & . \\
\hline Paspalum vaginatum & I & III & . & . \\
\hline Agrostis pseudopungens & II & II & . & . \\
\hline Triglochin striata & . & V & . & . \\
\hline Triglochin barrelieri & . & . & $\mathrm{V}$ & $\mathrm{V}$ \\
\hline Limonium ferulaceum & . & . & IV & $\mathrm{V}$ \\
\hline Polygonum equisetiforme & . & . & IV & IV \\
\hline Centaurium tenuiflorum & . & . & I & I \\
\hline Limonium diffusum & . & . & . & $\mathrm{V}$ \\
\hline Limonium algarvense & . & . & . & $\mathrm{V}$ \\
\hline Frankenia boissieri & & & & III \\
\hline
\end{tabular}

Characteristics of Molinio-Arrhenatheretea

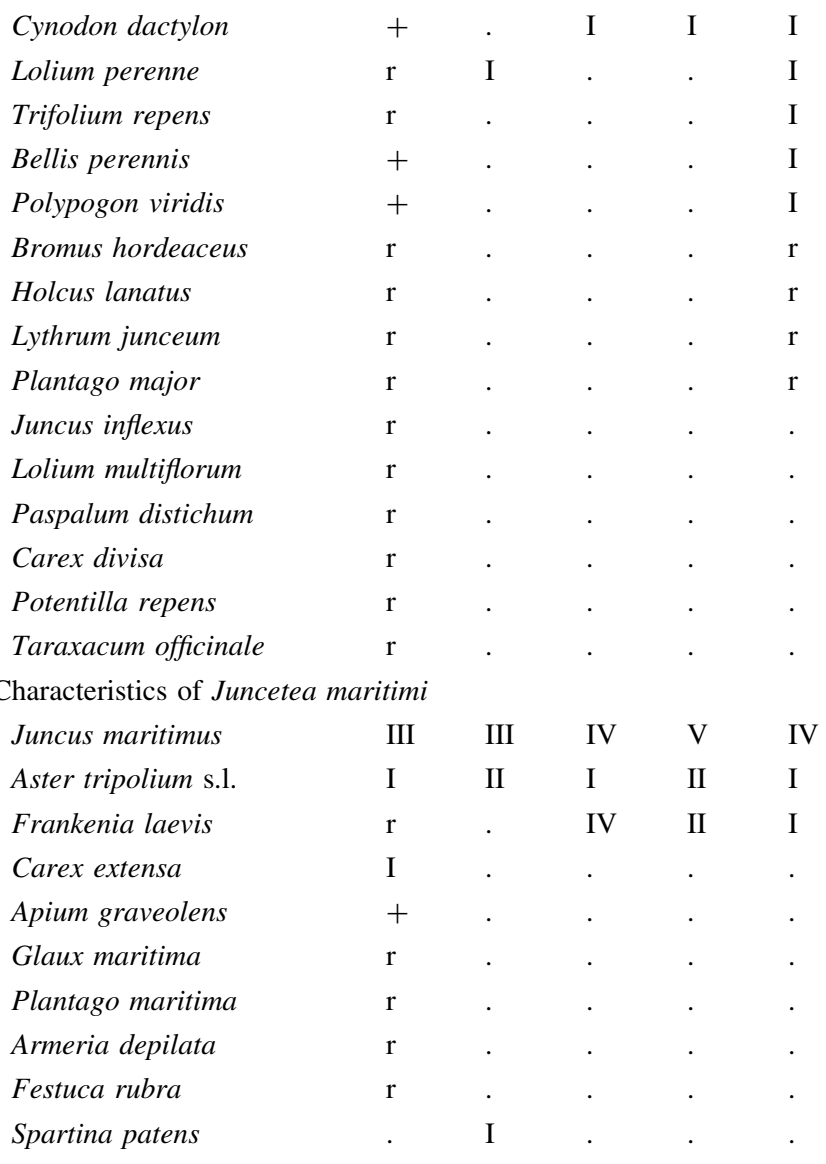

Table 1 continued

\begin{tabular}{|c|c|c|c|c|c|}
\hline Community type & 1 & 2 & 3 & 4 & 5 \\
\hline Number of relevés & 58 & 10 & 8 & 7 & 10 \\
\hline Spergularia media & . & . & IV & IV & IV \\
\hline Blackstonia imperfoliata & . & . & . & I & I \\
\hline \multicolumn{6}{|c|}{ Characteristics of Sarcocornietea fruticosae } \\
\hline Sarcocornia perennis & + & . & . & . & . \\
\hline Halimione portulacoides & $\mathrm{r}$ & . & II & I & II \\
\hline Inula crithmoides & . & . & II & III & III \\
\hline Limonium lanceolatum & & & II & & II \\
\hline
\end{tabular}

Characteristics of Saginetea maritimae

$\begin{array}{llllll}\text { Parapholis incurva } & \text { I } & . & \text { II } & \text { II } & \text { II } \\ \text { Polypogon maritimus } & . & \text { III } & \text { IV } & \text { V } & \text { IV } \\ \text { Parapholis filiformis } & . & . & \text { IV } & \text { V } & \text { IV } \\ \text { Centaurium spicatum } & . & . & . & \text { III } & \text { III } \\ \text { Hordeum marinum } & . & . & \text { II } & \text { III } & \text { II }\end{array}$

Characteristics of Isoeto-Nanojuncetea

$\begin{array}{llllll}\text { Isolepis cernua } & \text { II } & . & . & . & \text {. } \\ \text { Isolepis setacea } & \mathrm{r} & . & . & . & \text {. } \\ \text { Lythrum hyssopifolia } & \mathrm{r} & . & . & . & \text {. } \\ \text { Juncus bufonius } & \mathrm{r} & . & \text { II } & \text { II } & \text { II } \\ \text { Juncus hybridus } & \text {. } & \text {. } & \text { V } & \text { III } & \text { III }\end{array}$

Companions

\begin{tabular}{|c|c|c|c|c|}
\hline Plantago coronopus & I & I & IV & III \\
\hline Aster squamatus & + & I & . & III \\
\hline Atriplex prostrata & II & . & . & III \\
\hline Scirpus compactus & $\mathrm{I}$ & II & . & . \\
\hline Samolus valerandi & + & I & . & . \\
\hline Leontodon taraxacoides & $\mathrm{r}$ & I & . & . \\
\hline Salicornia sp. & $\mathrm{I}$ & . & . & . \\
\hline Lotus tenuis & $\mathrm{I}$ & . & . & . \\
\hline Elymus pycnanthus & + & . & . & . \\
\hline Polygonum aviculare & $\mathrm{r}$ & . & . & . \\
\hline Ranunculus sardous & $\mathrm{r}$ & . & . & . \\
\hline Trifolium squamosum & $\mathrm{r}$ & . & . & . \\
\hline Sonchus oleraceus & $\mathrm{r}$ & . & . & . \\
\hline Hordeum secalinum & $\mathrm{r}$ & . & . & . \\
\hline Carex cuprina & $\mathrm{r}$ & . & . & . \\
\hline Pulicaria dysenterica & $\mathrm{r}$ & . & . & . \\
\hline Sagina apetala & $\mathrm{r}$ & . & . & . \\
\hline Apium nodiflorum & $\mathrm{r}$ & . & . & . \\
\hline Centaurium acutiflorum & $\mathrm{r}$ & . & . & . \\
\hline Matricaria maritima & $\mathrm{r}$ & . & . & . \\
\hline Anagallis tenella & $\mathrm{r}$ & . & . & . \\
\hline Medicago lupulina & $\mathrm{r}$ & . & . & . \\
\hline Vicia nigra & $\mathrm{r}$ & . & . & . \\
\hline Phragmites australis & . & II & . & . \\
\hline Aetheorhiza bulbosa & . & . & I & . \\
\hline Melilotus messanensis & . & . & . & II \\
\hline Spergularia heldreichii & . & . & . & I \\
\hline
\end{tabular}


Table 1 continued

\begin{tabular}{llllll}
\hline Community type & 1 & 2 & 3 & 4 & 5 \\
Number of relevés & 58 & 10 & 8 & 7 & 10 \\
\hline Dittrichia revoluta &. &. &. & I & I \\
\hline
\end{tabular}

Frequency of plant species across relevés from each association or subassociation: 1 Spergulario marinae-Cotuletum coronopifoliae (BUENO 1997, table 23); 2 Triglochino striatae-Cotuletum coronopifoliae (ALVES 2004, table 1); 3 Cotulo coronopifoliae-Triglochinetum barrelieri typicum; 4 Cotulo coronopifoliae-Triglochinetum barrelieri limonietosum diffusae; 5 Clearings in rush-community without C. coronopifolia. Frequency classes are: V: $80-100 \%$ of the relevés, IV: 60-80\%, III: 40-60\%, II: 20-40\%, I: 10-20\%, +: 5-10\%, r: 1-5\%

occurring under the same abiotic conditions (Bueno 1997; Alves 2004).

\section{Materials and methods}

Vegetation relevés were made between 2006 and 2008 at the sites found during the last 20 years in the southwest part of the Iberian Peninsula (Fig. 1) that were taken as a representative sample of $C$. coronopifolia communities, namely those with presence of $C$. coronopifolia with cover $>20 \%$ in small ponds within clearings of undisturbed J. maritimus communities. A total of 15 relevés were made, the area of which ranged from 1 to $6 \mathrm{~m}^{2}$ based on an estimate of the minimum sampling area. Relevés where also made in clearings corresponding to analogous habitat conditions to those occupied by $C$. coronopifolia, as perceived by the researchers. The later relevés-those not having C. coronopifolia - are used informally as a 'post hoc null hypothesis' concerning similar habitat conditions for comparison sake in the final synthetic table.

For the comparison with northern Iberian communities, original relevés dominated by $C$. coronopifolia were obtained from the authors (relevés 16-25 from Alves 2004, and relevés 26-83 from Bueno 1997). Relevés were submitted to principal coordinate analysis (PCoA), based on log-transformed percentage cover and with the similarity ratio as resemblance measure using SYNTAX 2000 software (Gower 1966; Podani 2001). Principal coordinate analysis (PCoA) is a multidimensional scaling method that can be based on any similarity or dissimilarity index, making possible the use of ecologically meaningful indices (Chae and Warde 2006).

The biogeographical and bioclimatological typologies used in the description of syntaxa follow Costa et al. (1999), Rivas-Martínez et al. (2001, 2002) and RivasMartínez (2007), while syntaxa nomenclature follows the International Code of Phytosociological Nomenclature (Weber et al. 2000). Botanical nomenclature follows
Castroviejo et al. (1986-2006), Franco (1971, 1984), Franco and Rocha Afonso (1994, 1998, 2003).

\section{Results and discussion}

Distribution and species composition of Cotula coronopifolia communities in Iberia

Within Iberian Peninsula, C. coronopifolia is frequently associated to the sub-halophilous inner part of salt marshes. These sites are characterized by a strong fluctuation of soil salinity between wintertime, with the incoming of fresh water due to rainfall, and summertime, dry and hot, with the increase of soil salt concentration owing to the capillary rising of water from the saline phreatic sheet. In the Iberian Peninsula, these communities of small plants are always linked to sites where the higher hemicriptophytic vegetation has been destroyed, which also the high constancy of Spergularia marina in all Iberian C. coronopifolia communities (Table 1). S. marina is a species which makes extensive seed banks (Ungar 1998) and whose germination is light requiring (Thompson and Grime 1979; Carter and Ungar 2004), so that its occurrence depends on frequent disturbances. This explains the presence of $S$. marina with C. coronopifolia in gaps among J. maritimus communities' openings of the inner part of salt marshes, where human influence is most significant.

In the dry-thermomediterranean bioclimate of southern Iberia (Coastal Lusitan-Andalusian province), communities of $C$. coronopifolia develop during late spring and early summer They are co-dominated by $C$. coronopifolia and Triglochin bulbosa ssp. barrelieri, accompanied by characteristic species of the Juncetea maritimi class as well as the Sarcocornietea fruticosa, Saginetea maritimae, IsoetoNanojuncetea, and nitrophilous species, as shown in Table 2.

Compared to the other Iberian communities dominated by $C$. coronopifolia and $S$. marina, the southern Iberian communities present an original floristic composition. In particular, they differ from the Atlantic communities on the Galician-Portuguese and Cantabrian shores by the presence of Mediterranean species, such as Triglochin bulbosa ssp. barrelieri, Limonium ferulaceum, Parapholis filiformis, and by the absence of Eurosiberian species, such as Puccinellia fasciculata, P. maritima, Paspalum vaginatum, Triglochin striata, T. maritima, Agrostis stolonifera var. pseudopungens, Parapholis strigosa, etc. (Table 1). These differences justify a new phytosociological designation.

We propose the name Cotulo coronopifoliae-Triglochinetum barrelieri ass. nova hoc loc (Table 2, typus relevé no. 2) for this new association. The optimal conditions for its development are depressions on sandy-silty or silty-clayish 
Table 2 Vegetation relevés in Cotulo coronopifoliae-Triglochinetum barrelieri communities

\begin{tabular}{|c|c|c|c|c|c|c|c|c|c|c|c|c|c|c|c|}
\hline Relevé number & 1 & 2 & 3 & 4 & 5 & 6 & 7 & 8 & 9 & 10 & 11 & 12 & 13 & 14 & 15 \\
\hline Area of the relevé $\left(\mathrm{m}^{2}\right)$ & 2 & 1 & 1 & 1 & 4 & 4 & 2 & 4 & 4 & 6 & 4 & 4 & 4 & 4 & 2 \\
\hline Number of species & 7 & 9 & 12 & 8 & 17 & 14 & 12 & 16 & 18 & 22 & 15 & 17 & 13 & 15 & 12 \\
\hline
\end{tabular}

Characteristics of the association

\begin{tabular}{|c|c|c|c|c|c|c|c|c|c|c|c|c|c|c|}
\hline Cotula coronopifolia & 3 & 2 & 3 & 3 & 3 & 3 & 1 & 3 & 3 & 3 & 2 & 3 & 2 & 3 \\
\hline Triglochin bulbosa ssp. barrelieri & 3 & 3 & 2 & 1 & 3 & 1 & 3 & 2 & 2 & 3 & 3 & 1 & 3 & 2 \\
\hline Limonium ferulaceum & . & 2 & 1 & . & 2 & 2 & 1 & 1 & 1 & + & 1 & + & 1 & . \\
\hline Juncus maritimus & 1 & 2 & . & 1 & 1 & + & 1 & 1 & 1 & 1 & 1 & . & 1 & 1 \\
\hline Spergularia media & + & . & + & . & . & + & + & 1 & 1 & 1 & + & . & r. & + \\
\hline Polygonum equisetiforme & . & . & . & + & 1 & + & + & 1 & + & 1 & . & 1 & 1 & . \\
\hline Inula crithmoides & . & . & + & . & + & . & . & . & . & + & . & . & 1 & + \\
\hline Frankenia laevis & . & . & . & 1 & 2 & 1 & 2 & 1 & . & . & . & + & r & + \\
\hline Halimione portulacoides & . & . & 1 & . & 1 & + & . & . & . & . & . & . & . & 1 \\
\hline Aster tripolium ssp. pannonicus & . & . & . & . & + & . & . & . & . & + & . & . & r. & 1 \\
\hline Limonium lanceolatum & . & . & . & . & . & 1 & . & + & . & . & . & . & . & . \\
\hline Centaurium tenuiflorum & . & . & . & . & . & . & . & + & 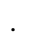 & 1 & . & . & . & . \\
\hline
\end{tabular}

Differentials of limonietosum diffusi subassociation

$\begin{array}{llllllllllllllll}\text { Limonium diffusum } & . & . & . & . & . & . & . & . & 1 & + & \mathbf{1} & + & 1 & + & 2 \\ \text { Limonium algarvense } & . & . & . & . & . & . & . & . & 1 & + & + & + & . & + \\ \text { Frankenia boissieri } & . & . & . & . & . & . & . & . & . & + & \mathbf{1} & 2 & . & . & .\end{array}$

Characteristics of Isoeto-Nanojuncetea

\begin{tabular}{|c|c|c|c|c|c|c|c|c|c|c|c|c|c|c|}
\hline Juncus hybridus & 2 & 2 & 3 & 3 & 1 & 1 & + & 2 & 1 & . & 1 & 2 & + & . \\
\hline Juncus bufonius & . & . & 1 & . & + & . & . & . & . & . & . & 1 & 1 & . \\
\hline \multicolumn{15}{|c|}{ Characteristics of Saginetea maritimae } \\
\hline Spergularia marina & 2 & 1 & 1 & 1 & 1 & 1 & 2 & 2 & 2 & 2 & 1 & 1 & . & 1 \\
\hline Polypogon maritimus & + & + & + & . & 1 & . & . & + & 1 & 1 & 2 & 1 & 2 & . \\
\hline Parapholis filiformis & . & 1 & . & . & 1 & 2 & 2 & 2 & 2 & 1 & + & 1 & 1 & 1 \\
\hline Hordeum marinum & . & - & 1 & . & . & . & . & + & 1 & . & + & + & . & . \\
\hline Parapholis incurva & . & . & . & 2 & + & . & . & . & + & . & . & + & . & . \\
\hline Centaurium spicatum & . & . & . & . & . & . & . & . & . & 1 & . & . & 1 & + \\
\hline
\end{tabular}

Companions

Plantago coronopus

Atriplex prostrata

Aster squamatus

Melilotus messanensis

Cynodon dactylon

Also: 2 Aetheorhiza bulbosa, 1 Lotus hispidus in 6; 1 Centaurium maritimum, + Blackstonia imperfoliata in 11; +Spergularia heldreichii in 13 , + Dittrichia viscosa ssp. revoluta in 14

Location of relevés: 1, 2, 3, 4 Hortas (Alcochete, Tagus river), 5 Praias do Sado (Setúbal, Sado River), 6 Vila Nova de Milfontes (Mira river), 7, 8 Amoreira (Aljezur); 9 Ria de Alvor (Portimão, Ria Formosa), 10 Quinta do Ludo (Loulé, Ria Formosa), 11, 12 Quinta de Marim (Olhão, Ria Formosa), 13 Ilha de Tavira (Ria Formosa), 14 Fuzeta (Olhão, Ria Formosa), 15 Bias do Sul (Olhão, Ria Formosa)

compact soils, temporarily inundated with brackish waters during winter and early spring (rainfall accumulates on small brackish ponds with salt content) and dried out in late spring or in the beginning of summer. The association can also be found along footpaths, which explains the abundant presence of ruderal and nitrophilous species. From a catenal point of view, $C$. coronopifoliae-T. barrelieri occurs in the high sub-halophilous salt marsh, occupying gaps within the Polygono equisetiformis-Juncetum maritimi (Fig. 2).
Due to differences in species composition between communities from the western and southern coast of the Coastal Lusitan-Andalusian province (Fig. 1), and taking into account that the definition of subassociations can be based on floristic differences related to biogeographic limits (Géhu and Rivas-Martínez 1981), we further propose the distinction of two subassociations: The typical subassociation, which dwells along the western coast (RibataganSadensean sector and Coastal Vincentine district), and the 
Fig. 2 Community types found in different microhabitats of the salt marsh of the Tagus Estuary (Central Portugal):

1 Spartinetum maritimae;

2 Puccinellio ibericae-

Sarcocornietum perennis;

3 Halimiono portulacoidis-

Sarcocornietum alpini;

4 Cistancho phelypaeae-

Sarcocornietum fruticosae;

5 Elytrigietum athericae;

6 Cistancho phelypaeae-

Suadetum verae; 7 Frankenio

laevis-Salsoletum vermiculatae;

8 Limonio vulgare-Juncetum

subulati; 9 Inulo crithmoidis-

Arthrocnemetum macrostachyi;

10 P. equisetiformis-J.

maritimi; 11 Cotulo

coronopifoliae-Triglochinetum

barrelieri; 12 Spartina

versicolor community. HT high tide, $S P$ spring tide
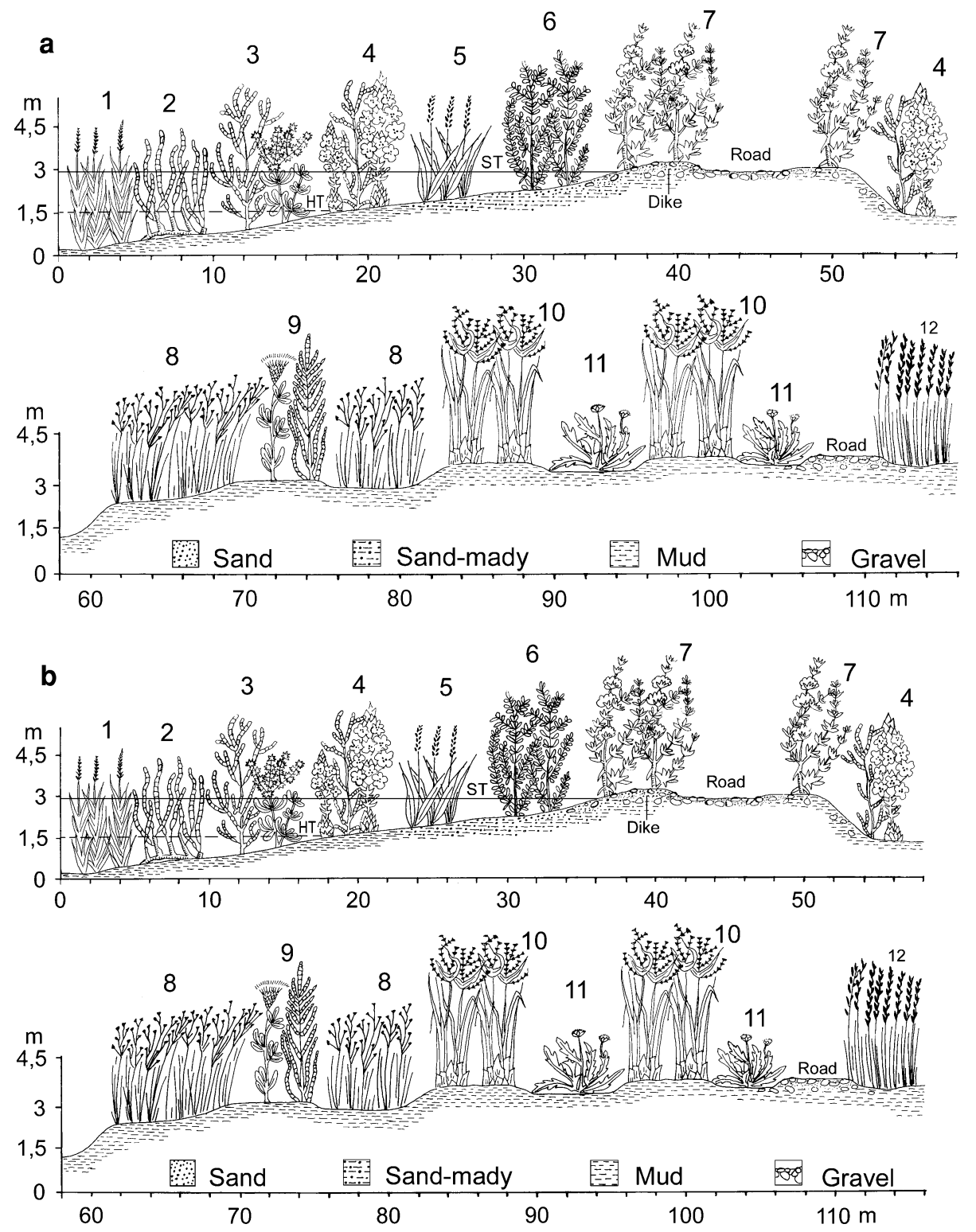

subassociation limonietosum diffusi along the southern coast (Algarvian district). Differential species of the subassociation limonietosum diffusi subass. nova hoc loc (relevés no. 9 to 15, Table 2, typus relevé no. 11) are Limonium diffusum, L. algarvense and Frankenia boissieri.

\section{Syntaxonomic classification}

Iberian C. coronopifolia communities recognized up to now have been positioned into the class Molinio-Arrhenatheretea (Rivas-Martínez et al. 2001, 2002; Table 3) because of the occasional presence of many characteristic species of this class (Table 1). This syntaxonomic classification does not seem appropriate for the southern communities for three main reasons:
1. With the exception of Cynodon dactylon, no MolinioArrhenatheretea taxa have been observed;

2. The co-dominant species Triglochin bulbosa ssp. barrelieri is a characteristic species of the Sarcocornietea fruticosae;

3. Characteristic species of the Sarcocornietea fruticosae and Juncetea maritimi are generally frequent.

We therefore propose to position the southern Iberian communities in the class Juncetea maritimi (Table 3).

The statistical analysis confirms that the relevés of the Mediterranean association are very different from the Cantabrian-Atlantic ones. Indeed, the ordination plots obtained with PCoA (Fig. 3) shows a group of relevés clearly separated from the remaining ones, which coincides with C. coronopifoliae-T. barrelieri (Group 1: relevés 1-15). 
Table 3 Syntaxonomical scheme proposed for coastal communities of Cotula coronopifolia (a) in southern Iberia (this study) and (b) in northern Iberia (Rivas-Martínez et al. 2001, 2002)

(a)

JunCetea Maritimi Br.-B1. in Br.-B1., Roussine \& Négre 1952

Juncetalia maritimi Br.-Bl. ex Horvatic 1934

Juncion maritimi Br.-B1. ex Horvatic 1934

Juncenion maritimi

Cotulo coronopifoliae-Triglochinetum barrelieri ass. nova hoc loc

Limonietosum diffusi subass. nova hoc loc

(b)

Molinio-Arrhenatheretea Tüxen 1937

Crypsio-Paspaletalia distichi Br.-B1. in Br.-B1., Roussine \& Nègre 1952

Paspalo-Polypogonion viridis $\mathrm{Br}$--B1. in $\mathrm{Br}$.-B1., Roussine \& Nègre 1952

Spergulario-Paspalenion vaginati Bueno \& F. Prieto in Bueno (1997)

Spergulario marinae-Cotuletum coronopifoliae Bueno \& F. Prieto in Bueno (1997)

Triglochino striatae-Cotuletum coronopifoliae Alves 2004

There is also a segregation between the Triglochino striataeCotuletum coronopifoliae (Group 2: 16-25) and Spergulario marinae-Cotuletum coronopifoliae (Group 3: 26-83), but they are closer to each other. The clear separation between the Mediterranean and the Cantabrian-Atlantic communities along the first axis justifies their inclusion in two different phytosociological classes (Table 3).

Plant communities occurring in similar habitats as the C. coronopifoliae-Triglochinetum barrelieri, but from which $C$. coronopifolia is absent, have the same native species composition, except for the occasional occurrence of characteristic species of the Molinio-Arrhenatheretea (Table 1). The combination of several high-rank characteristic species of Juncetea maritimi or MolinioArrhenatheretea (Table 1) is a peculiarity of these communities, which does not contravene considering them as an association of its own. However, the presence of C. coronopifolia itself appears not to be necessary to the development of the association. Since $C$. coronopifolia is a potentially invasive alien species, this fact suggests that where the species occurs, it occupies clearings in the rushcommunity created by a disturbance without preventing the subsequent establishment of a distinct native community that is specific to these habitats.

Ecological and biogeographic differentiation

The differentiation between the various associations of C. coronopifolia here can be explained with both ecological and biogeographic factors. All associations occur at sites with similar edaphic condition, but with different bioclimate. Climatically, the two associations existing in the north of the Iberian Peninsula belong to the Eurosiberian bioclimatic region. The Spergulario marinae-Cotuletum coronopifoliae occurs on the northern coast (Fig. 1), with humid to subhumid-thermotemperate bioclimate, whereas the Triglochino striatae-Cotuletum coronopifoliae occurs on the north-western coast, with humid to subhumidmesomediterrenean bioclimate (Alves 2004). This community differs from the former one by the presence of Triglochin striata and Polypogon maritimus and by the absence of Puccinellia fasciculata, Parapholis strigosa, Juncus ambiguus and J. gerardi, reflecting the hotter summer and therefore slightly more saline conditions.
Fig. 3 Principal coordinates analysis $(\mathrm{PCoA})$ of vegetation relevés in Iberian Cotula coronopifolia communities, with different symbols for the three associations (Table 1)

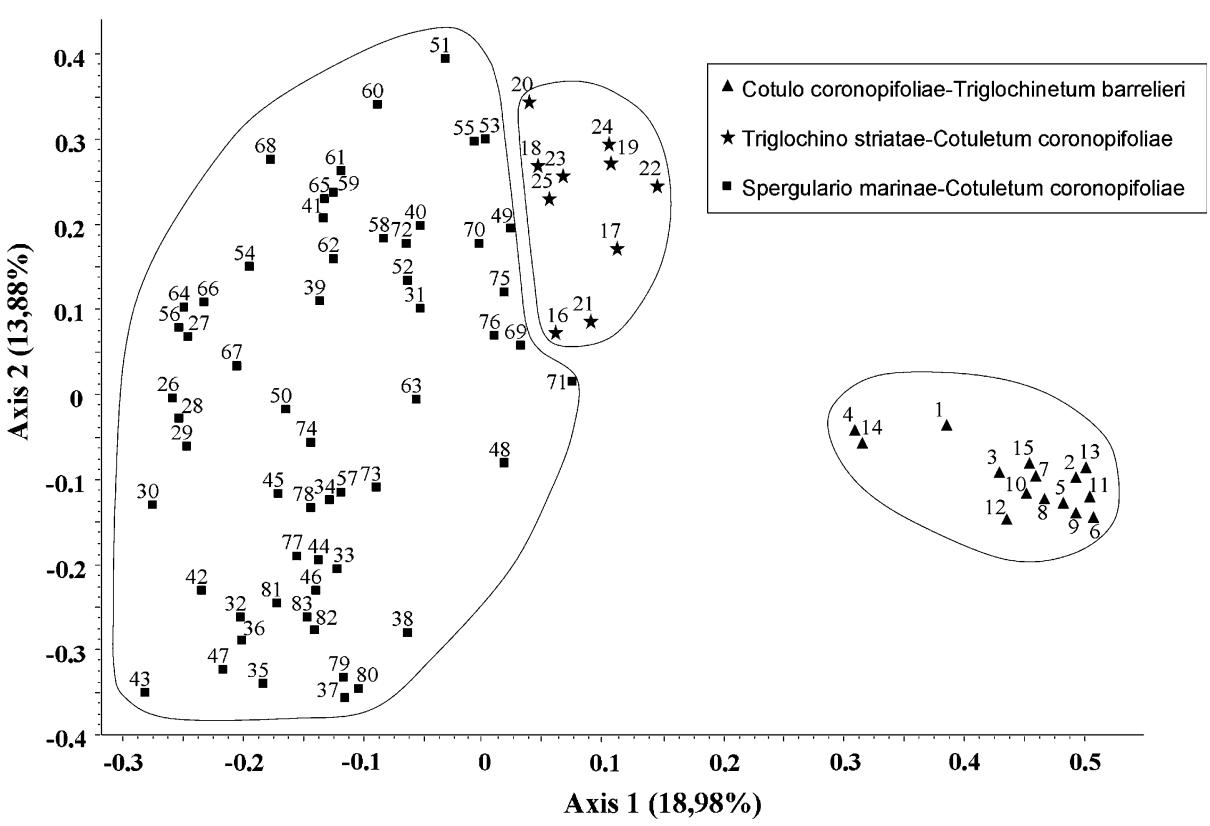


Communities from southern Iberia are characterized by the absence of Triglochin maritima and T. striata and the presence of $T$. bulbosa ssp. barrelieri. These congeners are vicarious species. The first one is an Atlantic species, while the third is a Mediterranean species and can be found only south of the Tagus Estuary (Costa et al. 2009). Triglochin striata is a neophyte from the Austral-Asian, South African and American territories, whose occurrence in Iberia is restricted to the north-western coast (Izco et al. 1992; Franco and Rocha Afonso 1994).

Besides this biogeographic distinction, northern and southern communities also differ ecologically due to the different climate. In northern Iberia (Cantabrian-Atlantic Province) the salt rising is low, owing to the humid climate (Díaz González and Fernández Prieto 2005) while in southern Iberia the upper salt marsh becomes saltier as a consequence of dryer and warmer summers, thus fresh water species are lacking (Costa et al. 1997). Therefore the communities where $C$. coronopifolia is present in north and southwest of the Iberian Peninsula are in different phytosociological classes, and only the southern ones belong to the typical halophytic communities. A similar distinction between more or less halophytic communities dominated by $C$. coronopifolia but associated with different species has been described for Chile (Ramírez et al. 1987; San Martín et al. 2006).

\section{Conclusions}

Invasion by $C$. coronopifolia has apparently not led to the significant disappearance of characteristic native species since most of these can still be found in the C. coronopifolia relevés. We also found no evidence of a homogenization of the invaded vegetation. Rather, communities dominated by this exotic plant invader are still diverse and reflect variation in ecological conditions as well as biogeographic limits similarly to native plant communities. Nevertheless, we cannot exclude the possibility that native communities could in the future suffer from a reduced area of potential habitat due to C. coronopifolia expansion.

\section{Sommario}

Studiando la composizione floristica, l'ecologia e la corologia delle comunità dominate da $C$. coronopifolia e Spergularia marina, si è scoperto che frequentemente occupano aperture nella vegetazione perenne più alta, nella zona interna sub-alofila delle praterie e fruticeti alofil. Negli ultimi venti anni sono stati condotti numerosi rilevamenti nel sud del Portogallo continentale che hanno messo in evidenza differenze di composizione floristica rispetto a comunità simili della Penisola Iberica. Si propone di conseguenza una nuova associazione: C. coronopifoliae-Triglochinetum barrelieri. Questa comunità si incontra in aperture di formazioni di Juncus maritimus, solitamente in piccole pozze temporaneamente inondate con acqua salmastra durante l'inverno ma secche in estate. È presente predominantemente negli estuari termomediterranei Ribatagano-Sadensi e Costiero Vicentini, ma per il distretto Algarviano é stata identificata una nuova sub-associazione, limonietosum diffusi.

L'analisi statistica (Analisi delle coordinate principaliPCoA) eseguita con tutti i rilevamenti pubblicati della penisola Iberica evidenzia una netta distinzione tra tre differenti comunità dominate da $C$. coronopifolia, sottolineando la peculiarità floristica della nuova associazione nei confronti di quelle Cantabro-Atlantiche.

Acknowledgments The authors would like to thank the anonymous reviewers for their constructive comments and also S. Güsewell, whose suggestions much improved the manuscript.

\section{References}

Alves P (2004) Sobre as comunidades de Cotula coronopifolia $\mathrm{L}$. do litoral português. Quercetea 4:151-155

Bueno A. 1997. Flora y vegetación de los estuarios asturianos. Cuadernos de Medio Ambiente Naturaleza 3, Servicio Central de Publicaciones del Principado de Asturias

Campos JA, Herrera M, Biurrun I, Loidi J (2004) The role of alien plants in the natural coastal vegetation in central-northern Spain. Biodivers Conserv 13:2275-2293

Carter C, Ungar IA (2004) Relationships between seed germinability of Spergularia marina (Caryophyllaceae) and the formation of zonal communities in an inland salt marsh. Ann Bot 93:119-125

Castroviejo S, Laínz M, López González G, Monserrat P, Muñoz Garmendia F, Paiva J, Villar L (eds) (1986-2007) Flora Iberica, Vols I-VIII, X, XIV, XV, XVIII, XXI. Real Jardín Botánico de Madrid, CSIC, Madrid

Chae S, Warde W (2006) Effect of using principal coordinates and principal components on retrieval of clusters. Comput Stat Data Anal 50:1407-1417

Costa JC, Lousã M, Espírito Santo MD (1997) Vegetação do Parque Natural da Ria Formosa. Stud. Bot 15:69-157

Costa JC, Aguiar C, Capelo J, Lousã M, Neto C (1999) Biogeografia de Portugal Continental. Quercetea 0:5-56

Costa JC, Arsénio P, Monteiro-Henriques T, Neto C, Pereira E, Almeida T, Izco J (2009) Finding the boundary between Eurosiberian and Mediterranean salt marshes. J Coast Res 56:1340-1344 (special issue)

Coutinho AXP (1939) Flora de Portugal. Bertrand, Lisboa

Díaz González TE, Fernández Prieto JA (2005) Prados y pastos cantábricos: origen y diversidad". In: Roza Delgado B. de la, Martínez Fernández A, Carballal Samalea A (eds) Producciones agroganaderas: Gestión eficiente y conservación del medio natural, vol II. Actas de la XLV Reunión Científica de la Sociedad Española para el Estudio de los Pastos, 699-729

Franco JA (1971) Nova Flora de Portugal (Continente e Açores) Lycopodiaceae-Umbelliferae, vol I, Author Edition, Lisboa 
Franco JA (1984) Nova Flora de Portugal (Continente e Açores) Clethraceae-Compositae, vol II, Author Edition, Lisboa

Franco JA, Rocha Afonso MA (1994) Nova Flora de Portugal (Continente e Açores)-Alismataceae-Iridaceae, vol III(1), Escolar Editora, Lisboa

Franco JA, Rocha Afonso MA (1998) Nova Flora de Portugal (Continente e Açores)-Gramineae, vol III(2), Escolar Editora, Lisboa

Franco JA, Rocha Afonso MA (2003) Nova Flora de Portugal (Continente e Açores)—Juncaceae-Orchidaceae, vol III(3), Escolar Editora, Lisboa

Géhu J-M, Rivas-Martínez S (1981) Notions fondamentales de phytosociologie. In: Dierschke H (ed) Syntaxonomie. J Cramer Vaduz 5-33

Gower JC (1966) Some distance properties of latent root and vector methods used in multivariate analysis. Biometrika 53(3/4):325338

Hultén E (1968) Flora of Alaska and Neighbouring Territories. Stanford University Press, Stanford, CA

Izco J, Guitán P, Sánchez JM (1992) La marisma superior cántabroatlántica meridional: estudio de las comunidades de Juncus maritimus y Elymus pycnanthus. Lazaroa 13:149-169

Manning J, Golblatt P (1996) West Coast. South African Wild Flower Guide 7. Botanical Society of South Africa, Kirsstenboch

Partridge TR, Wilson JB (1987) Germination in relation to salinity in some plants of salt marshes in Otago, New Zealand. N Z J Bot 25:255-261

Podani J (2001) Syn-Tax 2000. Computer programs for data analysis in ecology and systematics. Scientia Publishing, Budapest

Ramírez C, San Martín J, San Martín C, Contreras D (1987) Estudio florístico y vegetacional de la laguna El Peral, Quinta Región de Chile. Revista Geogr. de Valparaíso 18:105-120

Ramírez C, San Martín C, Contreras D, San Martín J (1989) Flora de las marismas del centro-sur de Chile. Medio Ambiente 10(2):11-24

Rivas-Martínez S (2005) Notions on dynamic-catenal phytosociology as a basis of landscape science. Plant Biosyst 139(2):135-144
Rivas-Martínez S (2007) Mapas de series, geoseries y geopermaseries de vegetación de España Memoria del mapa de vegetación potencial de España. Parte I, Itinera Geobotanica 17:5-436

Rivas-Martínez S, Fernández-González F, Loidi J, Lousã M, Penas A (2001) Syntaxonomical checklist of vascular plant communities of Spain and Portugal to association level. Itinera Geobotanica 14:5-341

Rivas-Martínez S, Díaz TE, Fernández-González F, Izco J, Loidi J, Lousã M, Penas A (2002) Vascular plant communities of Spain and Portugal. Addenda to the Syntaxonomical checklist of 2001. Itinera Geobotanica 15(1,2):5-922

San Martín C, Subiabre M, Ramírez C (2006) A floristic and vegetational study of a latitudinal gradient of salt marshes in South-Central Chile. Cien. Inv. Agr 33(1):33-40

Thiébaut G (2007) Non-indigenous aquatic and semiaquatic plant species in France. In: Francesca G (ed) Biological invaders in inland waters: Profiles, distribution, and threats, vol 2, pp 209229

Thompson K, Grime JP (1979) Seasonal variation in the seed banks of herbaceous species in ten contrasting habitats. J Ecol 67:893921

Ungar IA (1998) Are biotic factors significant in influencing the distribution of halophytes in saline habitats? Bot Rev 64:176199

Van der Toorn J (1980) On the ecology of Cotula coronopifolia L. and Ranunculus sceleratus L. I. Geographic distribution, habitat, and field observation. Acta Bot. Neerl 29(5/6):385-396

Van der Toorn J, ten Hove HJ (1982) On the ecology of Cotula coronopifolia $\mathrm{L}$. and Ranunculus sceleratus $\mathrm{L}$. II. Experiment on germination, seed longevity, and seedling survival. Acta Oecol 3(17):409-418

Weber HE, Moravec J, Theurillat JP (2000) International code of phytosociological nomenclature, 3rd ed. J Veg Sci 11(5):739768 